\title{
Paperbacks in the College
}

\author{
By ARTHUR A. COHEN
}

The PAPER-BOUnd book revolution, as it has been called, is not a revolution. Most revolutions are violent, disturbing the social and cultural order, casting upon the dustbin of history not only the corrupt and the surpassed but the virtuous and desirable. Such revolutions are rather unselective-they fan out from their ideological center to encompass and overwhelm not only the bad, but the good. This revolution in the publishing of books is tame and civilized; it has driven out nothing, no dustbin of history is piled high with the flotsam and jetsam of its conquering ideology (although it may well be that the water level of the Hudson river may soon be displaced by the hundreds of thousands of junked paperbacks which it is, perhaps apocryphally, thought mass-market publishers have dumped there). If anything, the quiet paperback revolution has added possibilities to our culture without destroying any, has opened new opportunities without closing off those which already exist, has extended horizons without foreshortening those with which we are already familiar.

The revolution, moreover, has not been a revolution of ideas or intellectual substance, but a mild technological innovation united in questionable embrace with a transformation of the techniques of consumer distribution. Lest it be thought that the network of paperback bookshops, independent wholesalers, and general and college bookstore display of paperbacks represent a radical departure in the merchandising of consumer goods, it should be recalled that every other aspect of merchandising in the United States has undergone as radi-
Mr. Cohen is with the publishing firm of Holt, Rinehart, and Winston, New York.

cal if not more radical transformation during the past decade. This decade has seen the supermarket, the discount store, the shopping center, the highway emporium come into their own. It is only natural that the book industry should finally give expression to its own recessive genes in some exhibition of daring, and imagination, and salesmanship. And so we have had, in slightly less than eight years, the development of the "quality" paperback and the "quality" paperback publisher.

The characteristics which loosely confederate the more than forty publishers of higher priced paperback books are these: their dependence upon the organization of an already established clothbound publisher; the existence of numerous books in an already published backlist for which new demand can be generated by making them available in paperback editions; the possibility of developing an internal reprint program with relatively small investment of additional editorial and promotional personnel and expense; the availability of already existing mechanics of production and of distribution. This somewhat simplistic theory of paperback publishing has, however, innumerable pitfalls to which many publishers are already exposed. If publishing were really all that simple, our recommendation to an aspiring publisher of paperbacks would be to establish a good clothbound publishing program, develop it for fifty years, 
and then reprint its output. Alas, neither clothbound publishing nor paperbound publishing are without hazards. The process of transfer from the cloth book to the paper book is complicated immensely by different requirements and techniques of production; radically reduced markups and margins of profit; the demand for enormous volume to justify servicing the outlets of distribution, and vastly diversified distribution to justify inventory buildup and volume; a shift of emphasis from traditional means of advertising and promotion to more clearly precision-tooled methods of promotion. In short, the higher-priced paperback industry is a vast effort directed toward what is often an unimpressive commercial achievement. In unit sales, paperback publishers can produce staggering statistics, but in dollar volume and profit, their efforts are often pitiful. Moreover, as publishers naively continue to enter paperback publishing with blushing innocence and enthusiasm, the already crowded avenues of distribution become even more clogged. I venture to predict that during this year, the number of units sold of paperback books retailing at more than $\$ 1.00$ will once more substantially increase, but the share of the total volume which each publisher will enjoy will again decline, and unit sales of individual titles, advance orders taken by publishers' salesmen, and publishers printing orders will tend to decrease accordingly. This means only that a shake-out seems somewhat overdue, a shake-out which will return the university presses from competition with commercial publishers to the production of works of scholarship which would otherwise not find a publisher; the elimination of hundreds of marginal and secondary works by otherwise famous authors (all the works of Lionel Trilling, Jacques Barzun, Jean Paul Sartre, and the other major figures of this and every other culture do not require the dubious immortality of the paperback); the return of thousands of pleasant but antiquated works of scholarship to the outof-print bookstores from which they ought not to have been rescued. At the same time that a shake-out will produce a contraction of lines and numbers of titles, it will enable the bookstore owners-trade and college-to pick themselves off the floor, come out from behind the stacks of undistributed publishers' catalogs, peer out from behind the mountainous inventory, and begin to reorganize.

The one wholly optimistic sector of the paperback market is the impact which the paperback has had on the American teacher. One suspects that, of the nearly ten million dollars of higher priced paperbacks sold in 1961, well over half were sold on the college campuses of America. Colleges which, up until recently, offered little more than required textbooks, a dictionary, and a stack of the latest Peanuts now have modest selections of paperbacks. Larger colleges and universities, those with a major university bookstore or those serviced by several off-campus stores presently devote up to 60 per cent of their available floor space to the display of paperbacks. The college bookstore has taken the paperback to heart.

At the same time, there is the beginning of a transformation in American education to which the paperback is intimately conjoined. The young instructors and assistant professors of American colleges-those who completed their graduate studies during the past five years-have already experienced the impact of the paperback. Every graduate student who commenced teaching during recent years undoubtedly received, if he matriculated in English, philosophy, religion, history - a paperback education. The classics of the humanistic disciplines have been available in paperbacks for many years now. It is only 
natural that such a teacher recognizes that the paperback gave him the opportunity to read much, widely, and at relatively low cost. There is little question but that, given the opportunity to teach by the same means, he will do so. The paperback avails the teacher of the opportunity of exposing his students to the maximum range of new ideas and intellectual traditions, permits him to innovate, and affords him mobility and flexibility in the planning of his curriculum. More than all of these functional considerations, the teacher enjoys a freedom in teaching which the more traditional textbook anthology of readings and selections denies him. Undoubtedly the first penetration of the usual college textbook publishing program effected by the paperback has been the conventional world of the humanities anthology. Fewer and fewer teachers of this younger generation will have anything to do with a high-priced, predigested anthology when it is possible to create one's own curriculum through judicious selection of paperbacks. The student gets a whole book, not a snip and snap of great literature, for roughly the same amount of money.

At the same time that the teacher can now select his supplementary and collateral reading from the rich fare offered by paperback publishers, he will come to exercise the same discretionary control of the paperback as he has already exercised over the clothbound textbook. When publishers direct their eye of avarice to the college market, they can ill-afford to be naive, foolish, or observably corrupt. One of the pleasures of competitive publishing is that bad books pretending to be good books get clobbered in the market place (this is not to deny that bad books which pretend to be nothing other than bad books often wildly succeed, but one must grant that to be unabashedly meretricious has its commendable and insouciant charms).
This is not the case with the bad textbook. No textbook is ever bad in its publisher's eye. The eye may be jaundiced, but the university committee and adopting professor manage to apply mud to the jaundiced eye with considerable success. Bad textbooks can be and are superseded by good textbooks. The same will obtain in paperback publishing to the college market. I venture to suggest that, of the five paperback editions of Crime and Punishment, the nine editions of Madame Bovary, the seven editions of Joseph Andrews, the four editions of Anna Karenina (to cite but a few which I recall), a number will disappear. Publishers of classics, unlike nature, rarely abhor a vacuum. Precisely the opposite. The attitude of many paperback publishers is to fill the vacuum again and again, and fill it with the same books, in the same editions, with the same introductions. The assumption that price dictates all is by itself a precarious assumption. The cheaper, therefore, does not always drive out the more expensive if the more expensive is only slightly more, and much better. I should take issue to the extent of insisting that, if the price gap is relatively small, teachers will prefer the edition over one dollar to the edition under one dollar if the former is excellently printed on fine book papers, well-designed, sturdily bound, and carries in addition to a carefully proofread text an original and suggestive introduction. Such traditions of publishing, as exemplified by Rinehart Editions, Anchor Books, Meridian Books, Modern Library, and Vintage Books, should prevail in a discriminating market place.

The fact remains that all such paperback publishing for the college market as I have described cover very few sectors-albeit important sectors-of the university curriculum. Rinehart Editions, for example, are presently publishing classics of American and English literature, with occasional oblique glan- 
ces at European literature; Meridian Books is heavily committed with its $\mathrm{Me}$ ridian Documents of American History and its Living Age Books series to two relatively untapped markets for the college paperback; Anchor Books with its considerable spread has done a splendid job of publishing in the area of general science and will shortly issue a critical and exegetic Bible. Many other publishers do an occasional book here and there, which suggests their serious effort to explore the use of the paperback as a primary vehicle of college instruction. In principle, there is nothing which prevents the paperback from making considerable inroads into the traditional college textbook market. There is no reason why the English grammar, the introduction to psychology, the primary anthropology, American history, European literature, or philosophy textbook could not be a paperback; perhaps not a $\$ 1.50$ paperback, but surely no more than $\$ 2.50$, and $\$ 2.50$ is still a vast ways away from $\$ 6.00$ and $\$ 7.50$.

It would seem to me that, wherever the cost of composition is not belabored by complicated foreign terminologies, graphs, tables, charts, or statistical résumés, basic plant cost can be absorbed on a printing of 20,000 to 30,000 copies. Obviously it will be some time and several technological innovations later (the further development of cold typesetting or the elimination of conventional plating would be among these) before we could put introductory calculus, physics, or chemistry textbooks into paperback editions. This eventuality, however, should not be ruled out.

Since distribution of the college textbook is vastly more efficient than any other sector of the book industry-for the simple reason that the college-publisher has a smaller and economically more powerful community to whom he caters (namely, the teacher) - it would seem plausible to imagine that, if a pub- lisher really made available a brilliant introductory textbook in any discipline at a modest price, he could capture a very substantial portion of the market. There will be, no doubt, irredentist professors who will continue to prefer to crack the bindings of their hardbound books, shelve them and shield them with pleasure, and talk disparagingly of the paperback. Their number will decrease. It is in the nature of this economic system that they will decrease, for, as our economy finds it necessary to expend vaster and vaster sums of its capital wealth on such eccentric projects as rocketry, multimillion-dollar computers, and automation equipment, it will have fewer dollars to spend on less grandly priced items of the market place. It will certainly continue to pay the price for pins and needles, for toothpaste and gumdrops, because it is hard to imagine these items much cheaper than they already are; but when it is given the occasion to select between the same book (or rather the same subject matter) at a high price or at a modest price, it will come unfailingly to choose the latter. There is little hope of getting a Univac for twenty-five dollars down and twenty-six weeks to pay, or of getting gumdrops for nothing. But if there is a way of getting excellent books cheaper, existing book publishers had better find out how, and quickly, before they meet powerful competition from those who can and will.

Whatever hard days may come on the paperback industry, whatever shake-ups and -outs will take place, there is one splendid leveler to our conscience and performance as publishers: the college market. For it is college use of the paperback as a medium of fresh, diversified, and flexible instruction at low cost that must come to occupy an ever-larger role in the teaching of the American people. 